\title{
Aptian lithostratigraphy and biostratigraphy (foraminifera) of block 49 in the southern North Sea (U..K. sector)
}

\author{
STEPHEN CRITTENDEN \\ P. T. Panah Tiara, Jakarta, Indonesia, c/o Gearhart GeoConsultants Ltd., Howe Moss Drive, Kirkhill Industrial Estate, \\ Aberdeen AB2 0GL, Scotland
}

\begin{abstract}
Strata of Aptian age in block 49 of the southern North Sea (U.K.) are reviewed in terms of lithostratigraphy, wireline log character and foraminiferal fauna. In some boreholes, the basal part of the Middle Hoiland Shale Member is interpreted as Late Aptian in age while the Lower Holland Marl Member is interpreted as Late to Early Aptian in age. The foraminiferal biostratigraphy of the Aptian strata in the designated reference borehole, 49/25-1, for the Dutch lithostratigraphical scheme in the U.K. southern North Sea is discussed briefly.
\end{abstract}

\section{INTRODUCTION}

This article discusses the recognition of Aptian age strata in the southern North Sea Basin in terms of lithostratigraphy and foraminiferal biostratigraphy. In order to present a clear picture some repetition (almost verbatim) is necessary of statements made in a previous publication (Crittenden, 1984b). The overall aim of this article is to contribute to the at present meagre knowledge of U.K. Aptian micropalaeontology and stratigraphy.

Strata of Aptian age in boreholes in block 49 of the U.K. southern North Sea Basin (Fig. 1) can be recognised by distinct lithological and wireline $\log$ characteristics (low gamma ray log response and low interval transit times of the sonic log response). This permits broad correlation with other boreholes in the southern North Sea (Crittenden, 1982a), the central North Sea, the Netherlands (e.g. L5-1, N.A.M. \& R.G.D., 1980) and with areas further afield such as Germany (e.g. Scheerhorn Oilfield, boreholes I46 and H1, Kemper, 1979) and Scandinavia (e.g. Dansk Nordsø E-1, I-1 and J-1, Rasmussen, 1978).

Lithostratigraphically, strata of Aptian age comprise the whole of the Lower Holland Marl Member equivalent of the Holland Formation (Rijnland Group) as defined by N.A.M. \& R.G.D. (1980), and in some boreholes includes the basal portion of the Middle Holland Shale Member equivalent. The "basal sand" horizon of the Middle Holland Shale Member equivalent may be the lateral equivalent of the Holland Greensand Member (Fig. 2). These lithostratigraphical units can be dated in gross terms by the contained foraminiferal faunas (Crittenden, 1984a, 1984b). Borehole 49/25-1 (Shell/Esso) is used to illustrate strata of Aptian age in the U.K. southern North Sea.

\section{LITHOSTRATIGRAPHY}

A synthesis of Early Cretaceous lithostratigraphical schemes for the southern North Sea Basin has been discussed previously (Crittenden, 1982a). A comparison of the Dutch scheme (N.A.M. \& R.G.D., 1980) with the British scheme (Rhys, 1974) concluded that the Dutch scheme offered more scope and finesse for correlation purposes. It was considered pertinent therefore to designate borehole $49 / 25-1$ as the reference borehole for the Dutch lithostratigraphical scheme in the British sector of the southern North Sea (Crittenden, 1982a). In addition, Crittenden (1982a) made the comment that Deegan \& Scull (1977) recognised units of formation status in the Cromer Knoll Group of the northern and central North Sea that were undefined because of data restriction.

Hesjedal \& Hamar (1983) have since illustrated an Early Cretaceous lithostratigraphical scheme for the southern Norwegian sector of the central North Sea which illustrates several formations within the Cromer Knoll Group. Hesjedal \& Hamar (198.3) presented a comparison and a general synthesis of the various lithostratigraphical schemes in use for the Early Cretaceous strata of northwest Europe but omitted any discussion of the scheme of N.A.M. \& R.G.D. (1980).

The Aptian to Early and Middle Albian age Sola Formation of Hesjedal \& Hamar (1983) of the central Graben and Norwegian - Danish Basin of the North Sea would appear to be the time equivalent of the Middle Holland Shale Member and part of the Lower Holland Marl Member. The Kopervik Formation would appear to be analogous to the Holland Greensand member. The Utvik Formation (upper calcareous shales and marls and marly limestones) of Hesjedal \& Hamar (1983) appears to be analogous to the cal- 


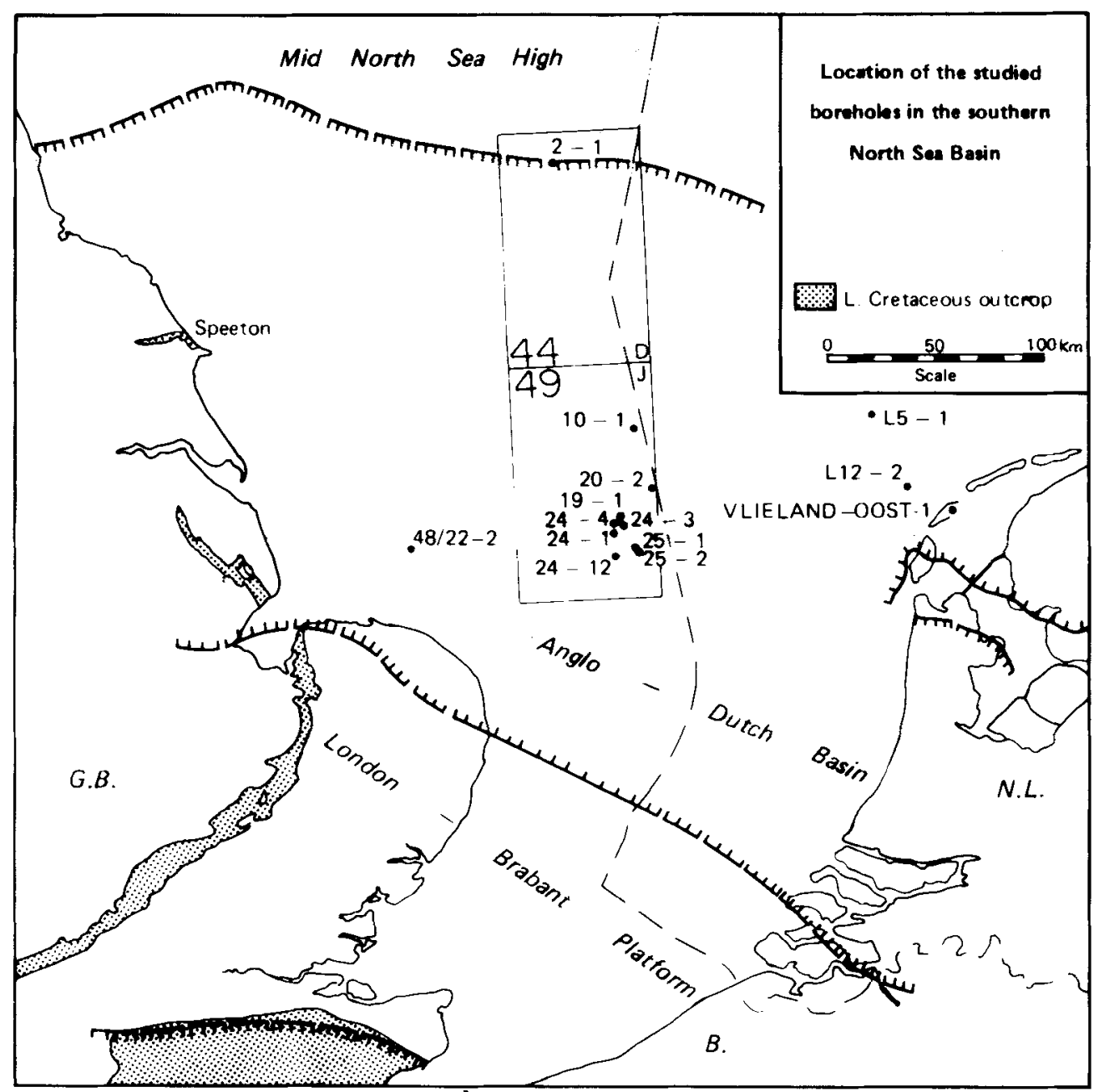

Fig. 1. Location of the studied boreholes in the southern North Sea Basin (Crittenden, 1982a).

careous claystone/clay limestone of the Lower Holland Marl Member.

All of the aforementioned lithostratigraphical studies have aided the understanding of the geological development of the North Sea Basin during the Early Cretaceous. It is apparent that as more detailed attention, due to hydrocarbon exploration, has been paid to the Early Cretaceous strata of the North Sea Basin the various lithostratigraphical models proposed have progressed from the simplistic (e.g. Deegan \& Scull, 1977) to the complex (N.A.M. \& R.G.D., 1980). This is the inevitable consequence of the acquisition of more and more data.

From a comparison of the lithostratigraphical schemes available it can be concluded that different areas of the North Sea region during the Early Cretaceous were characterised by broadly similar patterns of sedimentation. These patterns are the results of similar genetic processes and environments of deposition (Ziegler, 1982).
The various basins and sub-basins within the North Sea region during the Early Cretaceous underwent the same, or very similar, stratigraphic development related to local tectonics (and salt movement) and regional tectonics (e.g. associated with the development of the North Atlantic). This concept is invaluable when assessing the possibility of hydrocarbon traps (particularly stratigraphic plays) in the Early Cretaceous strata of the whole of the North Sea Basin (i.e. source rock potential, reservoir potential, trapping and sealing potential and migration pathways).

The scheme of N.A.M. \& R.G.D. (1980) and the Aptian strata of boreholes in block 49 , in particular borehole 49/25-1, are discussed in this paper.

\section{Middle Holland Shale Member}

This member, predominantly of Albian age, consists of grey-brown and green, micaceous claystones which are glauconitic and calcareous. It has a lower lime content than the lower and upper members of the 


\begin{tabular}{|c|c|c|}
\hline \multicolumn{2}{|c|}{ LITHOSTRATIGRAPHY (modified from NAM \& RGD, 1980) } & STAGE \\
\hline TEXEL GREENSAND MEMBER & TEXEL CHALK FORMATION & CENOMANIAN \\
\hline UPPER HOLLAND MARL MEMBER & & \\
\hline MIDDLE HOLLAND SHALE MEMBER & HOLLAND FORMATION & ALBIAN \\
\hline HOLLAND GREENSAND MEMBER' & & \\
\hline LOWER HOLLAND MARL MEMBER & & APTIAN \\
\hline
\end{tabular}

Fig. 2. Diagram to show the lithostratigraphic members of the Holland Formation (from N.A.M. \& R.G.D., 1980).

Holland Formation. Near the base there is a thin glauconitic sand or siltstone horizon containing rare phosphatic pebbles. The designated Dutch reference borehole (N.A.M. \& R.G.D., 1980), L5-1 (N.A.M.) and the borehole Vlieland Oost-1 each show a typical development of this member (Fig. 3). This member is well developed in borehole $49 / 25-1$ of the study area (Fig. 4).

The coarser horizon at the base or toward the base of the unit, is depicted by the reduced gamma ray and increased sonic log responses (c. $2384 \mathrm{~m}$ in L5-1) and

\section{VLIELAND OOST - I}

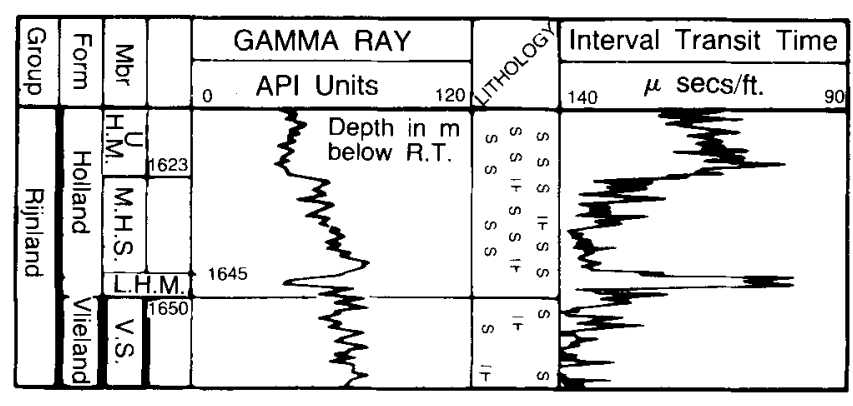

L5 - 1 (NAM)

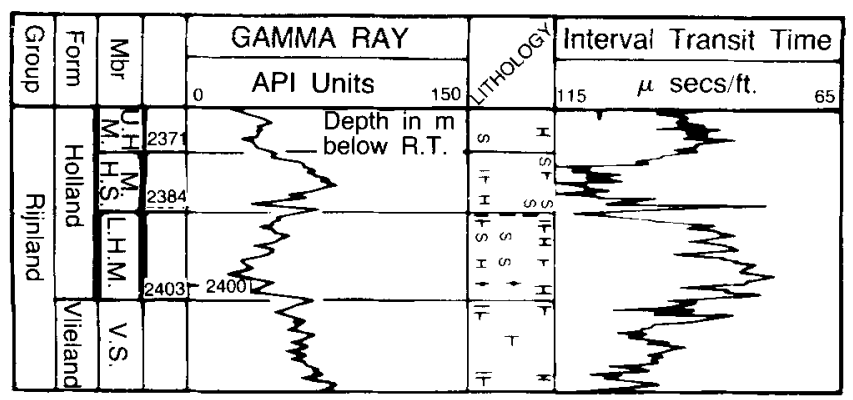

Fig. 3. The lithostratigraphy and wireline log character of the Holland Formation in boreholes L5-1 and Vlieland Oost-1 (from N.A.M. \& R.G.D., 1980). may be the lateral equivalent of the Holland Greensand Member of the West Netherlands Basin (Crittenden, 1984b). This interval may be the equivalent of the Carstone, Carstone Grit and the Greensand Streak in northeast England (Fig. 5).

The base of the Middle Holland Shale Member is not defined precisely by N.A.M. \& R.G.D. which can cause difficulty when attempting to use foraminiferal data for age dating the unit. Both boreholes L5-1 and Vlieland Oost-1 show a similar log response which in Vlieland Oost-1 $(1645 \mathrm{~m}-1650 \mathrm{~m})$ is interpreted as the Lower Holland Marl Member by N.A.M. \& R.G.D. (1980) and which in L5-1 (2380-2384m) is interpreted as the basal sand/siltstone of the Middle Holland Shale Member. The unit termed the Lower Holland Marl Member in Vlieland Oost-1 may be the basal sand/ siltstone of the Middle Holland Shale Member and represent the product of the "basal Albian" transgression (note the double point spike of the sonic log). This hypothesis, however, has not been confirmed or refuted by microfaunal analysis (by the present author) of these two boreholes. It is not clear where the base of this member should be drawn - at the lower sand/ siltstone horizon, if present, or beneath at the point where there is a pronounced log character change (lower gamma ray response and lower interval transit times). The latter case is taken by Crittenden (1982a).

\section{Holland Greensand Member}

N.A.M. \& R.G.D. (1980) define this member in the West Netherlands Basin as a green, very glauconitic, fine grained sandstone to siltstone, present only along the southern margin of the basin, which rapidly "shales out" to the north. According to N.A.M. \& R.G.D. (1980) this member is not present in borehole L5-1. However the present author is of the opinion that the sandy/silty horizon at approximately $2380 \mathrm{~m}-2384 \mathrm{~m}$ is the lateral equivalent of the Holland Greensand Member. The same unit may be recognised in boreholes $49 / 25-1$ at c.6425ft, $49 / 25-2$ at c.6795ft and 49/24-12 at c.5060ft (see Fig. 7). 
Crittenden

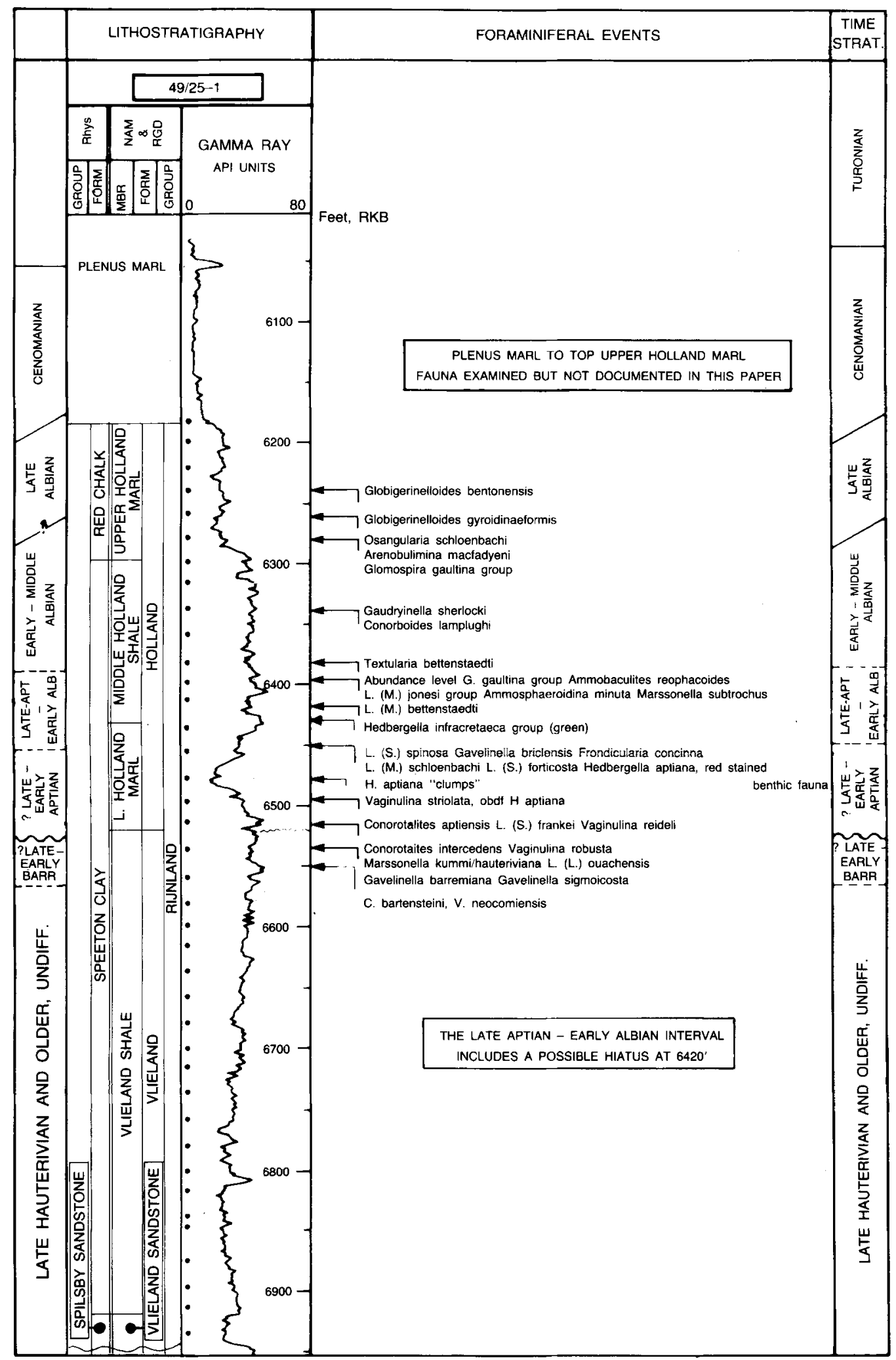

Fig. 4. The Aptian lithostratigraphy and biostratigraphy of borehole 49/25-1, southern North Sea Basin. 


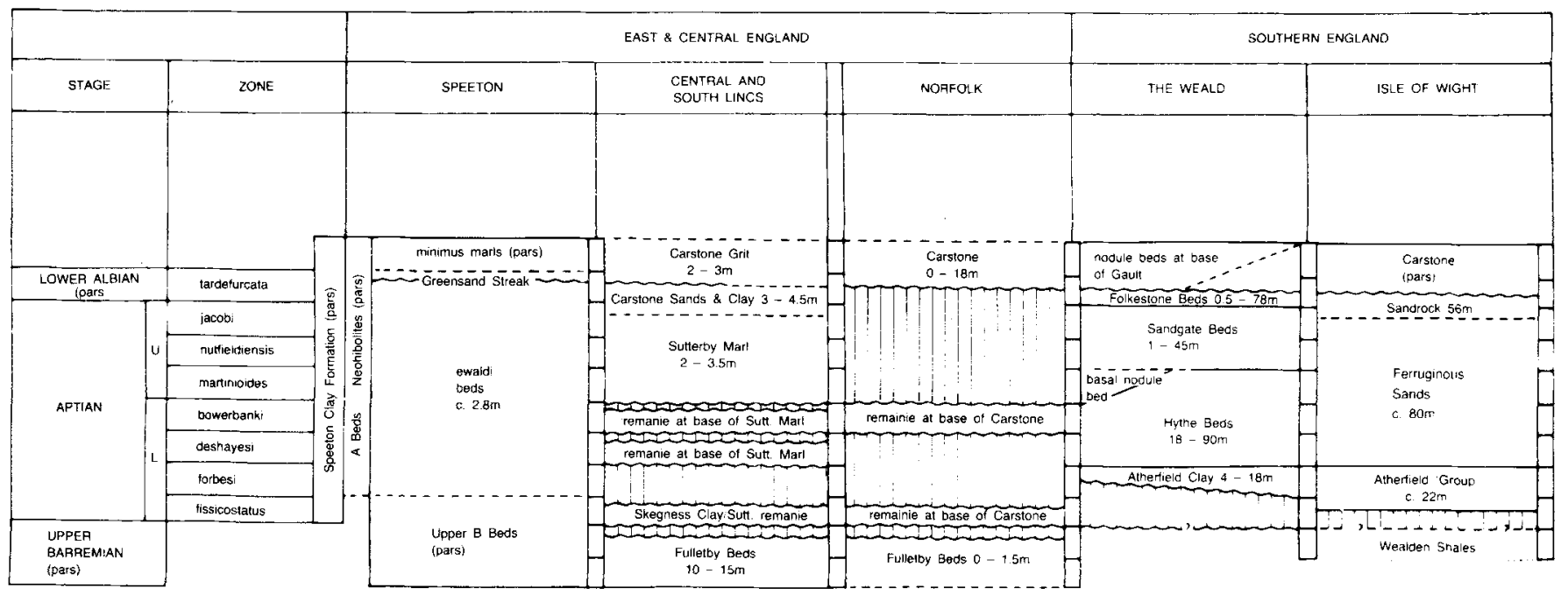

Fig. 5. A correlation of Aptian strata across southern, east and central England (from Rawson et al., 1978).

N.A.M. \& R.G.D. (1980) point out that the base of the Middle Holland Shale Member marks a pronounced transgression ("Albian transgression"). They include the thin coarse clastic beds denoting this transgression within the Middle Holland Shale Member rather than suggesting that they may be the lateral equivalent of the Holland Greensand Member. This same transgression may be seen in the Scheerhorn Oilfield (Fig. 6). In this oilfield the unconformity is pre-nolani-jacobi Biozone (Aptian age) in borehole $\mathrm{H}-1$ but is of pre-tardefurcata Biozone (Early Albian age) in borehole $\mathrm{I} 46$.

The exact position of these lithostratigraphic units and boundaries poses a problem when attempting to integrate the biostratigraphic data with the lithostratigraphic data. This is, as previously mentioned, further complicated by the nature of the samples (ditch cuttings) and sample interval.

\section{Lower Holland Marl Member}

This member is a grey and red-brown marl/calcareous claystone/very argillaceous limestone, with intercalated bituminous claystone beds. This member, as recognised by Crittenden (1982a) is of Aptian age. The whole unit is characterised by a low gamma ray log response and low interval transit times which are displayed as a "belly" motif. This member is well developed in borehole 49/25-1 of the study area (Fig. 4). This member is coeval with the "tock facies" and "ewaldi kreide" of Helgoland, and the "fischsheifer" and "ewaldi marl" of northwest Germany and the "ewaldi beds" of Speeton, U.K. (Bartenstein \& Kaever 1973; Kemper, 1973, 1979).

\section{BIOSTRATIGRAPHY}

Aptian age dating by means of foraminifera is hindered by a number of factors.

1. Imprecise knowledge of both Aptian foraminiferal (benthic and planktonic) faunas and the foraminiferal sequence across the Albian/Aptian boundary (Kent \& Dilley, 1968) in the adjacent onshore U.K. and northwest Europe (Crittenden, 1982b, 1983a,b,c, 1984a,b).

2. The geographical separation of the Albian and Aptian stratotypes in France (Rawson, 1983).

3. The locations of the Aptian stratotypes are in different faunal provinces. They fall within the tethyan realm in contrast to the boreal/transitional realm situation of the Early Cretaceous southern North Sea.

4. The material studied from the boreholes in block 49 is cuttings samples which hinders accurate biostratigraphic study (problems of caving. sample interval and lag time - see Crittenden, 1979). For this study there were no conventional core or sidewall core samples available for biostratigraphic analysis. A detailed discussion of the inherent disadvantages of borehole ditch cutting samples is considered unneccessary. A stratigrapher, to aquaint him herself fully with the problems, should ideally spend time at the wellsite calculating lag times and catching and preparing ditch cutting samples for analysis. Even so it is surprising how many micropalaeontologists do not appreciate how ditch cuttings are "caught" and thus cannot fully comprehend the disadvantages and drawbacks of using such samples for biostratigraphic analysis. 


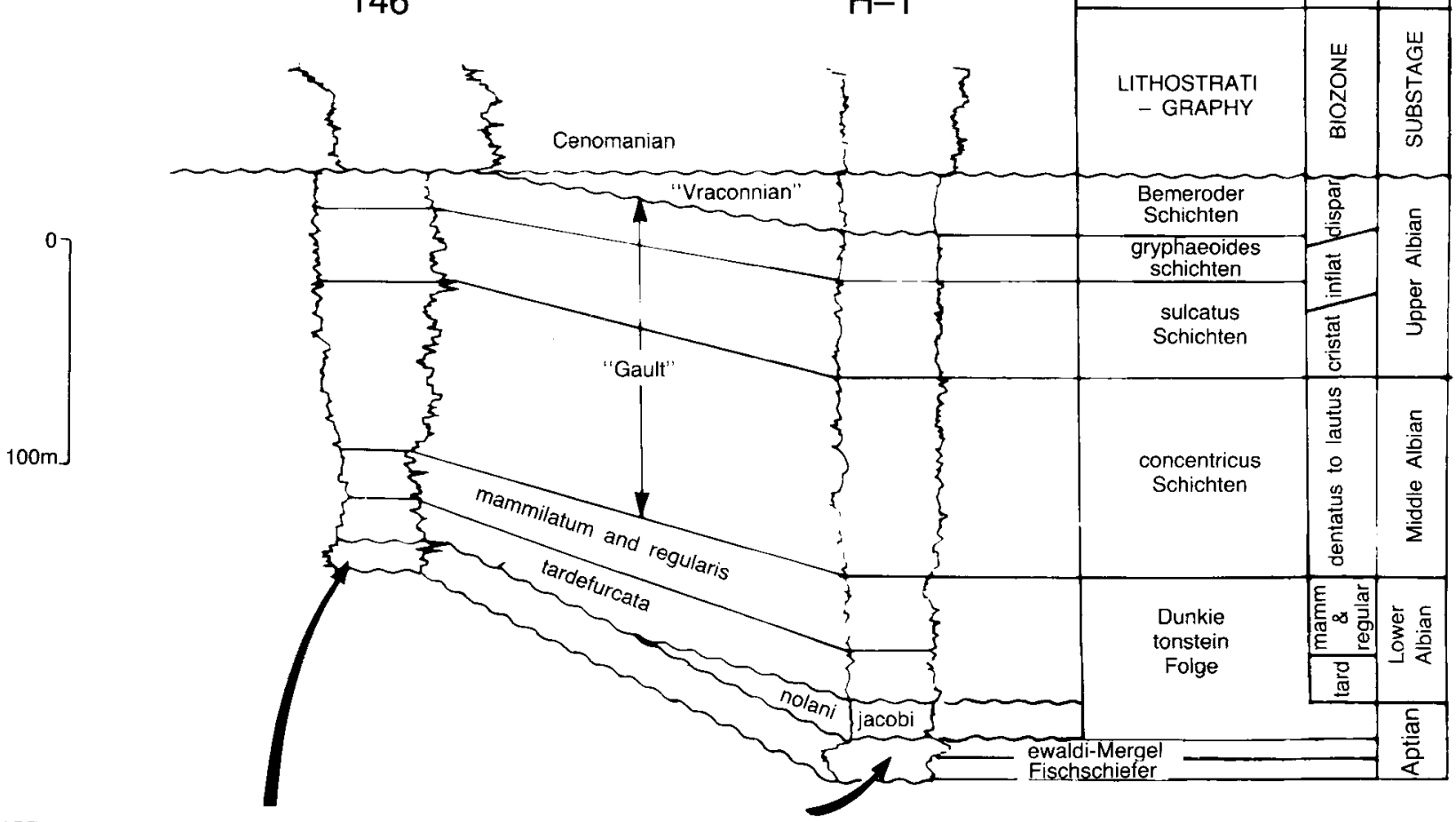

APTIAN "BELLY" MOTIF AS SEEN IN THE SOUTHERN NORTH SEA BASIN

Fig. 6. Profile through the Scheerhorn oil field to show the Aptian "belly" motif as seen in the southern North Sea Basin (after Kemper, 1979).

5. A very important consideration is the state of flux which exists in the erection of a foraminiferal biozonal scheme for the boreal Early Cretaceous strata of northwest Europe. This situation was recognised by Bartenstein \& Oertli (1977) who acknowledged the difficulties of comparing the stages of the Early Cretaceous in northwest Europe, as defined by ammonites, with a microfaunal subdivision. The division of the northwest European Early Cretaceous biozonal scheme (foraminifera and ostracods) of Bartenstein \& Bettenstaedt (1962) and the worldwide Early Cretaceous biozonal scheme (foraminifera) of Bartenstein (e.g. $1976 \mathrm{a}, \mathrm{b}, \mathrm{c}$ ) are in need of revision' (Bartenstein, 1978a). The schemes are dominated by the use of benthonic foraminifera.

The revised Aptian and Albian stages, in terms of their ammonite biozones, have been compared by Bartenstein (1978a) with the foraminiferal biozonation of Bartenstein \& Bettenstaedt (1962). The ammonite biozone boundaries do not coincide with extinctions, new appearances or major differences in the foraminiferal fauna (Bartenstein \& Kaever, 1973). To overcome this difficulty a complete revision of the Early Cretaceous index foraminiferal species and faunas is needed from samples of a section calibrated for a control by index ammonities (Bartenstein, 1978a).
Due to these factors it is considered improper to asume that, in all cases, foraminiferal age dating from ditch cuttings can provide accuracy to the limits of an ammonite biozone or subzone. However, the inability to provide an age in terms of an ammonite biozone or subzone must not be construed as a failing of foraminiferal biostratigraphy. Equally, the inability of ammonites to provide an age in terms of foraminiferal biozones or subzones must also not be construed as a failure of ammonite biostratigraphy. Kemper (1973) neatly sums up the problem "micropalaeontologists have created the problems through their biostratigraphical method - by giving ammonite bio zonal names to microfossil assemblages without finding the nominate ammonites, instead of proposing an autonomous classification".

\section{Middle Holland Shale Member}

This member is assumed by N.A.M. \& R.G.D. (1980) to be Early Albian in age. This is essentially correct as seen in boreholes in block 49 . However in the same boreholes studied in block 49 , the foraminiferal fauna in the basal part of this member has an earliest Early Albian/Late Aptian character (Crittenden 1984a,b). The Albian/Aptian boundary therefore falls somewhere toward the base of this member. This earliest Albian to latest Aptian age, from a synthesis of all the studied boreholes in block 49 , is suggested by the association (Hecht, 1938: with amendations per Bartenstein 1978a:- unpubl. research, Crittenden) of the following key benthic species: Textularia bettenstaedti 
Bartenstein \& Oertli ( $=T$. foeda Reuss of Eichenberg 1935, and Gaudryina D16 of Hecht, 1938), Ammosphaeroidina minuta Khan, Gaudryina dividens Grabert, Guadryinella sherlocki Bettenstaedt, Conorotalites aptiensis (Bettenstaedt), Haplophragmoides concavus (Chapman), Verneuilinoides subfiliformis Bartenstein, Marssonella subtrochus Bartenstein, Glomospira gr. gaultina (Berthelin) - green/red stain abundance, Falsogaudryinella spp. (= Uvigerinammina spp. of authors), Patellina sp., Lenticulina (Saracenaria) spinosa (Eichenberg), L. (Marginulina) schloenbachi (Reuss), L. (M.) foeda (Reuss), Nodosaria obscura (Reuss). The total fauna is dominated by arenaceous species which are usually crushed and deformed and is marked by a flood of $G$. gr. gaultina. This fauna compares very well with that recorded by Kent \& Dilley (1968) as Late Aptian - Early Albian in age from the Elsham Clay of Lincolnshire U.K.

The most reliable indication for a Late Aptian age is the co-occurrence of $T$. bettenstaedti, $L$. (S.) spinosa (top occurrence) and $G$. dividens, (Bartenstein \& Oertli, 1977) but equally the total fauna could be of earliest Early Albian age (Kent \& Dilley, 1968; Crittenden 1984a). The sample interval precludes precise biostratigraphic analysis of the basal part of this member in block 49 (see previous lithostratigraphical discussion).

The situation of the unconformities or unconformity at or near the Albian/Aptian boundary is complex and in some wells difficult to assess. The base of the Middle Holland Shale Member may be Early Albian in age as illustrated by borehole I46 (see Fig. 6) or Late Aptian in age as illustrated by borehole H1 (see Fig. 6) and depends on the structural position of the borehole and degree of overlap.

This paper assumes that the boundary of the Middle Holland Shale Member and Lower Holland Member is defined by the change to a consistent lower gamma ray response, i.e. the top of the "ewaldi Mergel" of Fig. 6.

An incoming downhole (in the basal Middle Holland Shale Member or top of the Lower Holland Marl Member depending on degree of hiatus) of abundant green coloured specimens of Hedbergella infracretacea (e.g. 49/24-1 and 49/24-12, 5060') together with $L$. (S.) spinosa and $G$. dividens is suggestive of the nolanijacobi Biozones of the Late Aptian (Bartenstein \& Kaever, 1973).

In some boreholes (e.g. 49/20-2) in the Lower Holland Marl Member, there is an additional flood of red coloured Hedbergella infracretacea (Hedbergella sp. D11, Hecht 1938) beneath, again in association with $L$. (S.) spinosa and $G$. dividens (nutfieldensis Biozone). By comparison with Heligoland, this association is indicative of the earliest Late Aptian (Bartenstein \& Kaever, 1973) and equated with the orange-red chalk of the upper ewaldi Kreide which is $2 \mathrm{~m}$ thick in Helgoland (Kemper et al., 1974). This same flood of planktonics is noted by Bertram \& Kemper (1982) in north-west Germany. In some boreholes in block 49, the strata beneath the "Albian unconformity" are Early Aptian in age and the distinctive flood horizon of $H$. infracretacea $(H . \mathrm{D} 11)$ is not observed (a result of erosion associated with a transgression or non-deposition on highs).

\section{Lower Holland Marl Member}

This member in boreholes from block 49 is characterised by the following benthic foraminiferal fauna: Ammobaculites reophacoides Bartenstein, G. sherlocki, $G$. dividens, $M$. subtrochus, Falsogaudryinella spp., $L .(M$.) bettenstaedti, $L$. (S.) frankei (ten Dam). L. (M.) schloenbachi, L. (S.) spinosa, L. (A.) subgaultina Bartenstein, C. aptiensis, Darbyella sp., G. brielensis Malapris, G. gr. gaultina, Vaginulina striolata Reuss, and $V$. reideli Bartenstein \& Brand, plus abundant small, crushed agglutinants (including Recurvoides spp.) (Crittenden 1984a,b).

This fauna is characteristic of the Early Aptian in northwest Germany and Heligoland (Bartenstein 1976a,b,c, 1977, 1978a,b,1979; Bartenstein \& Kaever, 1973)

In addition to the occurrence of planktonic foraminifera in the Lower Holland Marl Member (see above), the abundance of Hedbergella aptiana Bartenstein 1965 (= Hedbergella sp. D9, Hecht 1938) in the basal part of the Lower Holland Marl Member (49/24-12, 5100'), by comparison with Heligoland and northwest Germany, provides additional evidence of an Early Aptian age (Hecht, 1938; Bartenstein \& Kaever, 1973).

\section{BOREHOLE 49/25-1 - SYNOPSIS}

The development of strata of Aptian age in borehole 49/25-1 is typical for block 49 of the southern North Sea. The Aptian "belly" of the Lower Holland Marl Member of the Holland Formation is quite distinctive (gamma ray $\log$ and sonic $\log$ ) and reflects the increasing calcareous content of the sediments.

The biostratigraphic breakdown is as follows: strata of a Middle to Early Albian age overly an interval of strata of an Early Albian to Late Aptian age (6370'-80' to $\left.6450^{\prime}-60^{\prime}\right)$, which in turn overlies strata of Late? to Early Aptian age $\left(6450^{\prime}-60^{\prime}\right.$ to $\left.6510^{\prime}-20^{\prime}\right)$ (see Fig. 4).

The basal part of the Middle Holland Shale Member in borehole 49/25-1 is therefore Early Albian to Late Aptian in age, while the Lower Holland Marl Member is earliest Late Aptian to Early Aptian in age.

The base of the Lower Holland Marl Member is a minor unconformity and some Late Barremian sediments, from microfaunal evidence, are assumed to be missing in this borehole.

\section{Early Albian to Late Aptian age $\left(6370^{\prime}-6450\right.$ ')}

This interval includes the basal portion of the Middle Holland Shale Member and the upper portion of the 


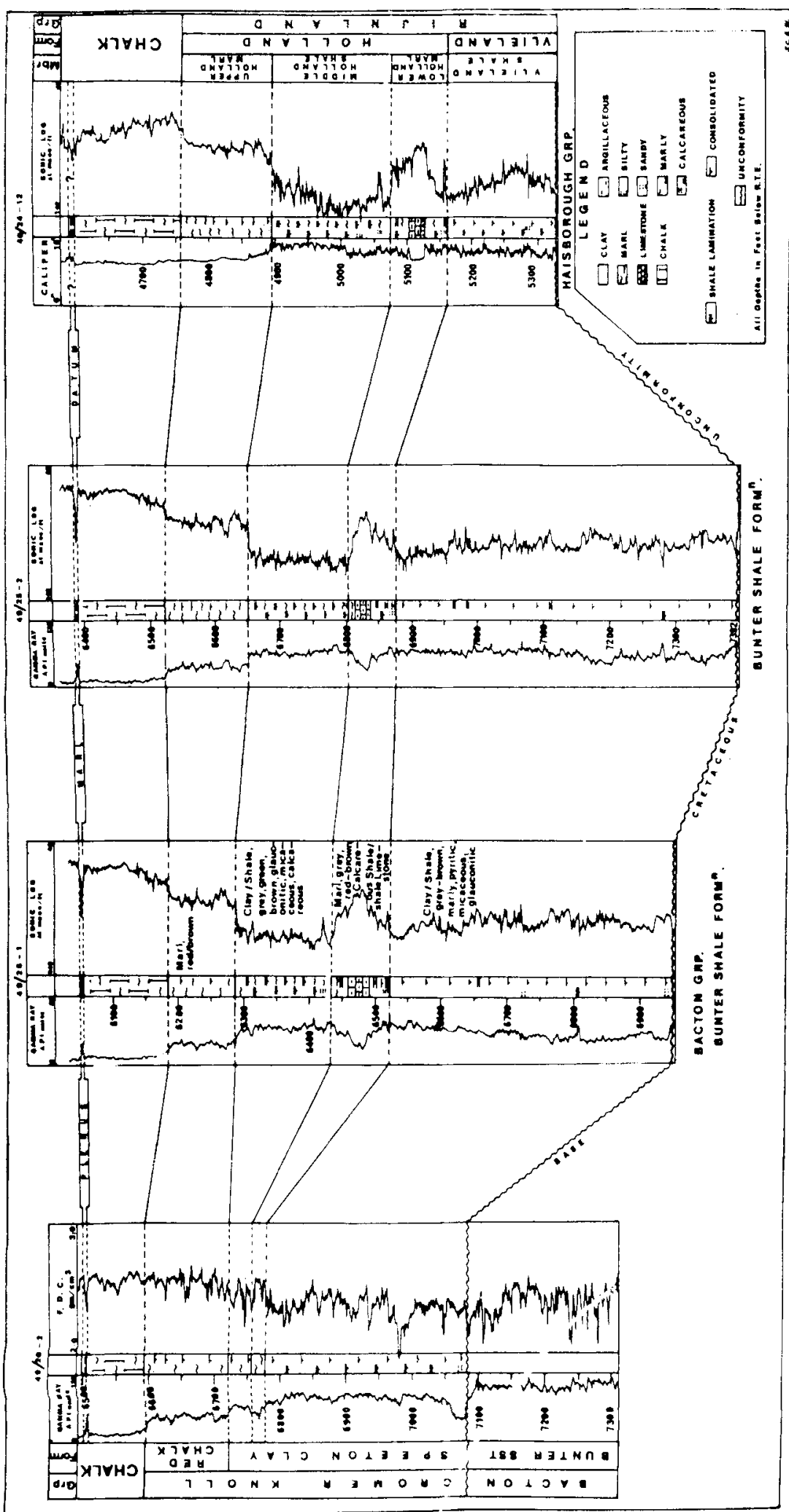

Fig. 7. A lithostratigraphical correlation of boreholes 49/20)-2. 49/25-1, 49/252 and 49/24-12 in the southern North Sea Basin showing the Aptian "belly" motif (from Crittenden, 1982a). 
Lower Holland Marl Member (the boundary between these two members is at $\left.6440^{\prime}\right)$. The sandy/siltstone horizon at $6420^{\prime}$ is assumed to be the lateral equivalent of the Holland Greensand Member and to represent the "basal Albian" transgression. The foraminiferal fauna of the whole interval is of Early Albian to Late Aptian age in aspect and is characterised by the top occurrence in this borehole of $T$. bettenstaedti $\left(6370^{\prime}\right)$. The occurrence of $A$. minuta, $M$. subtrochus, $A$. reophacoides, L. (M.) bettenstaedti, L. (M.) jonesi group and an abundance of Haplophragmoides concavus/nonioninoides group and $G$. gaultina further characterise the interval. At $6430^{\prime}$ a rare green stained, planktonic foraminiferal fauna occurs. A pragmatic approach could be taken and the conclusion made that the silty/sandy horizon at $6420^{\prime}$ is in fact the base of the Albian (Lott, Ball \& Wilkinson, 1985). This would indicate that the part of the Middle Holland Shale Member beneath this horizon is Late Aptian in age. However such a conclusion is not justified for this borehole based on the scanty foraminiferal evidence available. Onshore sequences in the U.K. in general show a condensation of strata during the Early Albian and Late Aptian resulting in remanie faunas, minor unconformities, non-sequences and hiatuses (Lower Greensand facies - see Rawson et al., 1978; Kent \& Dilley, 1968; Lott, Ball \& Wilkinson, 1985).

\section{Late? to Early Aptian age $(6450$ '-6520')}

The top of this interval in this borehole is defined by the first downhole occurrence of a red stained benthic foraminiferal fauna and the topmost occurrence of Lenticulina (S.) spinosa, G. brielensis, F. concinna, $L$. (M.) schloenbachi and $L$. (S.) forticostata. Red stained planktonic foraminifera of the $H$. delrioensis $-H$. infracretacea plexus are also present but are rare in number $\left(6450^{\prime}\right)$. This rare planktonic fauna, if in place, suggests an earliest Late Aptian age (Bartenstein \& Kaever, 1973). The characteristic flood occurrence of red stained Hedbergellids was not observed in this borehole. Grey coloured specimens of $H$. aptiana are also present (derived from the limestone), and in sample 6470-80' are common and occur in clumps. In sample 6490-6500' there is a flood occurrence of grey/white coloured $H$. aptiana. This planktonic fauna is characteristic of the Early Aptian in northwest Germany (Bartenstein, 1965; Hecht, 193s: Bartenstein \& Kaever, 1973; Bartenstein, 1978:1). The basal part of this interval contains $C$. aptiensis and $l$. (S.) frankei, both of which characterise the Early Aptian. The sonic $\log$ feature at $6520^{\prime}$ probably represents an unconformity. This interval rests unconformably upon ?Late to Early Barremian age sediments.

?Late to Early Barremian age $\left(6520^{\prime}-6550\right.$ ')

The occurrence of $('$. intercedens, $V$. robusta, $M$. kummi/hauteriviana, L. (L.) ouachensis, and L. (L.) praegaultina at $6530^{\prime}$ indicates the penetration of sediments of ?Late to Early Barremian age (Bartenstein \& Bettenstaedt, 1962; Bartenstein, 1978a). This is coincident with a marked lithological change at $6520^{\prime}$ to a dark grey, micaceous, fissile claystone (the Vlieland Shale Member of the Vlieland formation). The occurrence of $G$. barremiana, $C$. bartensteini, G. sigmoicosta and $V$. neocomiensis at $6550^{\prime}$ indicates strata of an Early Barremian to Late Hauterivian age (Bartenstein \& Bettenstaedt, 1962; Bartenstein, 1978a).

\section{CONCLUSIONS}

Aptian strata in the North Sea Basin and the northwest European region are widespread and of diverse facies. The stratigraphic subdivision of the Aptian strata onshore is based on the study of the microfaunal, macrofaunal and lithological sequences encountered. The foraminiferal faunas contained in ditch cuttings from boreholes drilled offshore in the southern North Sea Basin, by comparison with dated Aptian age sections onshore in northwest Europe, indicate an Aptian age and provide a biostratigraphic subdivision of the established lithostratigraphic sequence used in the southern North Sea Early Cretaceous strata.

\section{ACKNOWLEDGEMENTS}

This article forms part of the author's research results obtained during a three year sojourn at the Plymouth Polytechnic. The research, which forms part of a programme of study for the degree of Ph.D., wàs jointly sponsored and fundéd by the Natural Environment Research Council U.K., and Shell Exploration and Production U.K. Ltd. under the auspices of a CASE award. To both institutions I extend my thanks. I am grateful to Professor Malcolm B. Hart, my research supervisor at Plymouth, for his guidance, criticism and encouragement. In addition, I would like to thank my ex-research colleague at Plymouth, Kim C. Ball for useful discussion. I thank my wife Carla for help in translating Dutch, German and French texts, and Hannah for her help with the artwork.

Manuscript received July 1985

Revised manuscript accepted June 1986

\section{REFERENCES}

Bartenstein, H. 1965. Taxionomische Revision und Nomenklature zu Franz E. Hecht - standard Gliederung der Nordwestdeutchen Unter - Kreide nach Foraminifera 1938. Teil 4, Albian. Senckenberg. leth., Frankfurt, 46, 4-6, 327-366.

Bartenstein, H. 1976a. Foraminiferal zonation of the Lower Cretaceous in north-west Germany and Trinidad, West Indies - an attempt. Nethes Jb. Geol. Palaont. Mh, Stuttgart, 3, 187-191. 
Bartenstein, H. 1976b. Practical applicability of a zonation with benthonic foraminifera in the worldwide Lower Cretaceous. Geologie Minjb., 54 (1-2), 83-86.

Bartenstein, H. 1976c. Benthonic index foraminifera in the Lower Cretaceous of the northern hemisphere between east Canada and northwest Germany. Erdol u. Kohle, Erdgas, Petrochemie, 29/6, 254-256.

Bartenstein, H. 1977. Stratigraphic parallelisation of the Lower Cretaceous in the Northern Hemisphere. Zonation with benthonic index foraminifera. Newsl. Stratigr., Stuttgart, 6 (1), 30-41.

Bartenstein, H. 1978a. Paleontological zonation. Parallelisation of the Lower Cretaceous Stages in north west Germany with index ammonites and index microfossils. Erdol u. Kohle, Erdgas, Petrochemie, 31/2, 65-67.

Bartenstein, H. 1978b. Phylogenetic sequences of Lower Cretaceous benthic foraminifera and their use in biostratigraphy. Geologie Mijnb., 57 (1), 19-24.

Bartenstein, H. 1979. Worldwide zonation of the Lower Cretaceous using benthonic foraminifera. Newsl. Stratigr., Stuttgart, 7 (3), 142-154.

Bartenstein, H. \& Bettenstaedt, F. 1962. Marine UnterKreide (Boreal und Tethys), - In: Leitfossilien der Mikropalaontologie, S 225-297, Tab 17-18, Taf 33-41, Berlin.

Bartenstein, H. \& Kaever, M. 1973. Die UnterKreide von Helgoland und Ihre Mikropalaeontologische Gliederung. Senckenberg. Leth. 54, 2-4, 107-164. Frankfurt.

Bartenstein, H. \& Oertli, H. J. 1977. Textularia bettenstaedti n.sp., approved benthonic index foraminifera in the Central European Lower Cretaceous. Neues. Jb. Geol. Palaont. Mh., 4-1, 15-24, Stuttgart.

Bertram, H. and Kemper, E. 1982. Die Foraminiferen des spaten Apt und fruhen Alb Nordwestdeutschlands. Geol. Jb., A65, 481-497, 3 Taf. Hannover.

Crittenden, S. 1979. Palaeocene and Eocene planktonic foraminifera from borehole 49/24-2 southern North Sea, Unpubl. M.Sc. thesis, Univ. of Wales, Aberystwyth, 136 pp, 7 pls.

Crittenden, S. 1982a. Lower Cretaceous lithostratigraphy N.E. of the Sole Pit area in the U.K. southern North Sea. Journ. Petroleum geol., London, 5, 2, 191-201.

Crittenden, S. 1982b. Rotaliine foraminiferids from the type section of the Atherfield "Group" (Lower Aptian), Isle of Wight, U.K., J. micropalaeontol., 1, 23-36.

Crittenden, S. 1983a. A foraminiferal analysis of the Atherfield Clay (Lower Aptian) of the Isle of Wight, U.K., with special emphasis on the arenaceous species. In: First Workshop on Arenaceous Foraminiferids, Amsterdam 1981, I.K.U. publication 108, 9-29, 2 pls.

Crittenden, S. 1983b. Osangularia schloenbachi (Reuss, 1863), an index foraminiferid species from the Middle Albian to Late Aptian of the southern North Sea. Neues. Jb. Geol. Palaont. Abh., 167/1, 40-64.

Crittenden, S. 1983c. The Lenticulina (Astacolus) humilis (Reuss, 1863) group and Lenticulina (Astacolus) atherfieldensis (new species) in the Lower Aptian of the Isle of Wight (U.K.). Cretaceous Research, 4, 349-359.

Crittenden, S. 1984a. A preliminary account of Aptian benthic foraminifera from the southern North Sea (U.K. Sector). In: Benthos '83, Second International Symposium on Benthic foraminifera. Bull. Cent. Rech. EPEA., Mem 6, 185-190.
Crittenden, S. 1984b. A note on the Early Cretaceous biostratigraphy (Foraminifera) of borehole 49/24-1 (Shell/ Esso) in the southern North Sea. J. micropalaeontol., 3 (1), $1-10$.

Crittenden, S. In press. The Albian transgression in the southern North Sea Basin. Journ. Petroleum geol.

Deegan, C. E. \& Scull, B. J. 1977. A standard lithostratigraphic nomenclature for the Central and northern North Sea. Rep. Inst. Geol. Sci., 77/25. Oljedirektoratet Bull., 1, 1-36.

Eichenberg, W. 1935. Microfaunen-Tafels zur Bestimmung von UnterKreide-Horizonten in Bohrkernen norddeustscher oelfelder. Oel und Kohle, 2, Pt 23.

Hecht, F. E. 1938. Standard Gliederung der Nordwestdeutschen Unter Kreide nach Foraminifera. Abh. Senckenb. naturforsch. Ges., Frankfurt, 443, 1-42.

Hesjedal, A. \& Hamer, G. P. 1983. Lower Cretaceous stratigraphy and tectonics of the south-southeastern Norwegion offshore. In: J. P. H. Kaasschieter and T. J. A. Reÿers (eds.): Petroleum geology of the southeastern North Sea and the adjacent onshore areas (The Hague, 1982), Geologie Minjb., 62, 135-144.

Kemper, E. 1973. The Aptian and Albian stages in northwest Germany. In: The Boreal Lower Cretaceous (Casey, $R$. and Rawson, P. F. ed.) Geol. J. Spec. Iss., 5, 345-360. Liverpool.

Kemper, E. 1979. Die UnterKreide Nordwestdeutschlands. Ein Uberblick. Aspekte der Kreide Europas. IUGS Series A., No. 6, 1-9. Stuttgart.

Kemper, E., Rawson, P. F., Schmid, C. \& Spaeth, Chr. 1974. Die Megafauna der Kreide von Helgoland und ihre biostratigraphische Deutung, Newsl. Stratigr., Stuttgart, 3, 121-137.

Kent, P. E. \& Dilley, F. C. 1968. The Jurassic-Cretaceous Junction at Elsham, North Lincolnshire. Proc. Yorks Geol. Soc., 36, 4 (29), 525-530.

Lott,- G. K., Ball, K. C. \& Wilkinson, I. P. 1985. Mid Cretaceous Stratigraphy of a cored borehole in the western part of the Central North Sea Basin. Proc. Yorks Geol. Soc., 45/4, 235-248.

Nederlandse Aardolie Maatschappij (N.A.M.) and Rijks Geologische Dienst (R.G.D.) 1980. Stratigraphic nomenclature of the Netherlands. Verh. van het Koninklijk Ned. Geologische Mijnbouw Kundig genootschap. 77 pp +36 enclosures. The Hague.

Rasmussen, L. B. 1978. Geological aspects of the Danish North Sea Sector. Denmarks geologiske Undersgelse (3), 44, 4-85.

Rawson, P. F. 1983. The Valanginian to Aptian stages current definitions and outstanding problems. Zitteliana, 10, 493-500. Munich.

Rhys, G. H. 1974 (Compiler). A proposed standard lithostratigraphical nomenclature for the whole of the U.K. North Sea. A report of the joint Oil Industry-Institute of Geological Sciences Committee on North Sea Nomenclature. Rep. Inst. Geol. Sci., London, 73/8, 14 pp.

Ziegler, P. A. 1982. Geological Atlas of Western and Central Europe. Shell Internationale Petroleum Maatschapp $\ddot{B}$ B.V., $1-130,40$ enclosures. Elsevier Scientific publishing Co. Amsterdam. 